\title{
Zonal-and-Wave Structure of Open Systems on Micro, Mega- and Macrolevels of the Universe
}

\author{
Oleh Khomenko
}

\author{
Doctor of Technical Science, Professor, Dnipro University of Technology (Dnipro, Ukraine) \\ E-mail: rudana.in.ua@gmail.com \\ https://orcid.org/0000-0001-7498-8494
}

\section{Tamara Barna}

\author{
Ph.D., Dnipro University of Technology (Dnipro, Ukraine) \\ E-mail: nv.ngu@ukr.net \\ https://orcid.org/0000-0002-3152-8778
}

\begin{abstract}
The analysis of formation of wave astrodynamics as the applied science that studying zonal-andwave structure of megasystems in the Universe is executed. The perspective of disclosure of physical essence of the phenomenon of rocks zonal disintegration around underground mine workings is analysed. The results of a research that received by means of well-known and new synergetic methods, which have discovered zonal-and-wave nature of the examined phenomenon, are described. The discovered phenomenon has been designated as zonal capsulation of mine working with definition of gradients of stresses, density, temperature and other factors of a power condition of the massif with formation of ring energy zones, their quantities, amount and shape, sinusoidal-and-wave stresses and ring areas of deformation. The regularities of distribution of matter and energy in systems with various large-scale levels have been investigated and accepted as comparative data for confirmation of level of convergence of the received results. Increase in large-scale level of system from micro to mega-and macrolevel led to equivalent increase in density of a core, constant of gravitation and the period of fluctuation of a surface, and the period of attenuation of wave fluctuations and a ratio of the sizes of energy zones remained constant. The received sedate dependence of a ratio of the sizes of energy zones for the examined systems coincides with the established verification of sedate dependences that describing a ratio of the sizes of energy zones in mine working's capsule which convergence reaches up to $100 \%$. The received results are the incontestable proof of the uniform nature of interaction of the open evolving systems at all large-scale levels and allows to draw analogies during development of methodological approaches to the solution of similar problems.
\end{abstract}

Keywords: wave astrodynamics; zonal disintegration of rocks; capsulation of mine working; largescale level of system; convergence of research results

Received: October 3, 2018; accepted: November 5, 2018

Philosophy and Cosmology, Volume 22, 2019: 24-32.

https://doi.org/10.29202/phil-cosm/22/3

(C) Khomenko, Oleh, 2019

(C) Barna, Tamara, 2019 


\section{Introduction}

Approaches to global space exploration are various, however the general principle in this process of transferring of learned laws on Earth on the surrounding megaworld and vice versa is remained. So, the idea of a zonal-and-wave structure of megasystems of the Universe has been positively apprehended by world scientific community. The new "quantum-mechanical" direction in astrophysics which has received the name "wave astrodynamics" claims that our Solar system, however, as well as any other planetary system and also the system of satellites around planets, has quite certain set of the spherical layers (zones) enclosed to each other between which it is necessary to look for moving bodies in open spaces. A sensational conclusion that the world surrounding us, generally consists of electronic waves which set makes the most part of mass of the Universe became a result of almost 20-year research of scientists. This fact also explains universal manifestation of zonal-and-wave distribution of matter and energy in the Solar system, fogs, meteorites, planets, stars, constellations, the majority of galaxies and other clusters of stars in the Universe [Chechelnitsky, 1980].

The phenomenon of zonal-and-wave distribution of matter has arisen long before emergence of the planet Earth and underlies in formation of space structures of all types. Well extending in solid, liquid and gaseous substances, waves play a fundamental role in a life of human. The wave phenomena underlies in all systems existing on Earth, processes and spheres of activity of the person and in this reason are studied by fundamental and applied sciences including geosciences, including geophysics, geodynamics, geomechanics, geoenergetics. The research of laws of zone distribution of matter and energy in the Universe has allowed to determine consistent patterns of formation of stress state of crust and to use maximally energy of rocks by underground mining of deposits on Earth and to develop methodological approach for exposure of similar regularities for other planets of Solar system, etc. [Khomenko, 2007].

\section{Analysis of scientific problem}

The phenomenon of zonal disintegration of rocks around mine workings till 2015 was considered as one of the most difficult problems of the mining science that corresponding to world level of scientific novelty. For the first time, this contradictory phenomenon has been discovered in 1972 on the mine of Republic of South Africa and then in USSR, Russia, Ukraine, Kazakhstan, USA, Japan and other countries of the world. Discovery has given understanding about formation of the self-organized ring structures around mine workings [Shemiakin et al., 1992; Kirichenko et al., 2002; Baisarov et al., 2006]. The paradoxicality of the phenomenon of zonal disintegration of rocks around mine workings was that it contradicts ideas of classical physics of a condition of solid bodies according to which the movement of the front of ultraboundary deformation from mine working's contour deep into the rock massif with formation of zones of elastic, elastic-plastic and plastic states is impossible. Unsuccessful attempts of the description of the physical processes that operating this phenomenon as with application of methods of classical mechanics, and new methods of rock science, have even more increased necessity of development of the synergetic methods of research that corresponding to modern ideas of interaction of matter and energy in the nature. With application of synergetic methodological search, we managed to disclose physical essence of the examined phenomenon and to designate it as a phenomenon of zonal capsulation of mine working by the system of ring energy zones [Kaido, 2009]. 
On the basis of conducted industrial (methods of observation and estimates, mine survey, unloadings of the massif, deformation of boreholes and deep reference points) [Khomenko et al., 2016: 1], laboratory (methods of equivalent, optical-and-polarizing and electrowire materials) [Khomenko et al., 2016: 2] and theoretical (finite element method and thermodynamic method) [Kononenko et al., 2016] research on formation of zonal structures around mine workings, a new classification of research methods of stress-strain state of rocks by means of well-known methods sorting on sign "the way of representation of the massif" has been offered. Also, the synergetic group of methods that consisting from thermodynamic method, a modifed entropy method as parts of the thermodynamic theory [Lavrinenko \& Lysak, 1977], and developed energy method [Khomenko, 2012] is entered. The system accounting of gradients of stresses, density, temperature and other factors of a power condition of rocks with formation of ring energy zones, their quantities, amount and shape, sinusoidal-and-wave stresses and ring areas of deformation has been executed by means of synergetic methods. Further, the mechanism of formation of safety capsules around mine workings has been described. These results have formed the basis of the energy theory about rock pressure on Earth [Khomenko, 2016: 3]. The executed industrial, laboratory and theoretical research with the help of well-known and newly developed synergetic methods of research had various reliability and convergence of results that determined necessity of the simulated technical parameters accuracy checking. We have in mind a depth of destruction of the massif around mine workings, quantity of the formed energy zones in the capsule and the sizes of these zones.

Results of the analysis have shown that by means of used methods of research, the sizes, shape and the number of areas of destruction of the massif adjoining development were determined. During theoretical and physical modeling, the sizes and quantity of energy zones and level of stresses of the massif in zones are examined in details. Determination of parameters in relative sizes has allowed conducting their comparative analysis. The applied methods were unequal both by opportunities of the modelled parameters, and on convergence of the received results. Therefore, the decision on necessity in identification of more general fundamental regularities and laws that describe a condition of open systems during various large-scale levels for the purpose of further comparison with the main results that were received during research of a phenomenon of zonal capsulation of mine workings has been executed [Khomenko, 2016].

\section{Results of research}

For confirmation of level of convergence of the received results, regularities of distribution of matter and energy in the systems of various large-scale levels have been investigated and accepted as comparative data. Any object of the world surrounding us, whether it be atom, the planet or the galaxy, is considered as the difficult, open and evolving system including components, organized on micro, macro- and megalevels. The general specific laws forming, connecting and operating micro, macro- and the megaworlds that are universal act on all levels, and connect energy and matter in the uniform system of interaction. Having revealed these general regularities and laws, we have obtained the incontestable evidence of convergence of the received results and a possibility of formation of methodological approach for their application at any large-scale level [Bolotov, 2012].

Megalevel. The phenomenon of zonal-and-wave distribution of substance in other clusters of stars in the Universe has arisen thanks to "Big Bang" $15-20$ billion years ago according to Gamov's theory of 1947 after which matter has begun to be condensed unevenly 
under action of longitudinal waves, forming various types of the condensed substance. The mass of similar non-uniformity reached 1015 Solar masses. Hot non-uniform plasma with alternation of concentration and depression corresponds to a picture in substance when sound waves are extending in it [Schmidt, 1957]. The theory of a zonal-and-wave structure of the Universe that had been offered by Albert Chechelnitsky in 1980, and received the name of wave astrodynamics and claims that Solar system, as well as any other planetary system, has a certain set of the ring zones enclosed to each other is considered as fundamental one. The Solar system is dynamic and megawave, and the size of megawaves is commensurable with sizes of Solar system, the galaxy "Milky Way", other galaxies and the Metagalaxy [Chechelnitsky, 1988]. In 1772, I. Titsius and I. Bode have established that the distance between orbits of planets doubles during transition from each of them to the following one, more remote from the Sun. This means that planets are possesed on strictly ordered distances. Orbits are subdivided on weak - unbalanced and strong - counterbalanced, with the largest celestial bodies [Nieto, 1976].

E. Andrade, P. Lebedev and M. Karnovsky's experiments on research of influence of the wave field on material objects have given an impetus for further development of the theory of wave processes at the megalevel. E. Andrade has established in vitro that wave process is the reason of power interactions between material objects. P. Lebedev and M. Karnovsky investigated interaction between acoustic, hydrodynamic and electromagnetic sources of waves that have identical character. This conclusion confirmed a hypothesis of the uniform wave nature of interaction on micro and macrolevels [Andrade et al., 1972]. Relying on these results, Yakov Kumchenko has offered a universal wave constant (C) for all discrete systems of the megaworld on the example of planets of Solar system $C=4 \pi^{2} R^{3} / M T_{n}^{2}=\rho T^{2} / 3 \pi=\gamma$ which is equal to gravitation $\gamma$ and connects among themselves radiuses of planets of $R$, the periods of their fluctuations of $T_{n}$, mass of planets and the Sun of $M$ and their density $\rho$. The received values of the periods coincided with the period of the Sun and the main tones of fluctuations of planets system and have allowed to draw a conclusion on power of Earth and planets of Solar system that cope the Universal wave source of energy (Table) [Kumchenko, 2006] for the author.

Macrolevel. According to Yakov Kumchenko's theory about Earth's formation under the influence of the Universal wave energy source that has created geodynamic, geophysical and gravitational conditions, stationary wave process $C=\rho T^{2} / 3 \pi=\gamma$ is its gravitational invariant. The author has received $C=\rho T_{E}^{2}=$ const, where $T_{E}$-period of fluctuations of a steady gravitational condition of Earth. Gravitational energy, being the smallest, operates by all other types of energy that much more exceed it. That event is explained by the reasonability of interaction between material medium of Earth as hierarchical system [Batiushkova, 1966; Yavorskiy \& Detlaf, 1965].

Leaning on a fundamental conclusion of P. Lebedev that acoustic, hydrodynamic and electromagnetic resonators have identical character of exchange of wave energy. It is possible to use results of analytical and physical research of A. Ivannikov, O. Tonakanov and other researchers of department of acoustics of MSU, who have established that the jet component of fluctuation enters planets from all directions and is perpendicular to their surfaces, and the active component has vortex character, than and their rotation means about. A constant for a surface pulsation case as wave source of a zero order, where $R-$ planet radius; $M$ - its weight; $\mathrm{T}_{p}$ - the period of a pulsation of a surface of the planet, (const $)_{n}$ - a constant for the pulsing planets. A constant $R^{3} / M T_{\text {rot }}^{2}=(\text { const })_{\text {rot }} \mathrm{f} \quad \mathrm{o} \quad \mathrm{r}$ rotation of the planet, where $T_{\text {rot }}$ - the period of rotation of the planet. At the same time, 
the periods of fluctuation of planet surfaces and the periods of their rotation are connected among themselves by equation $\mathrm{T}_{r o t}=9 \mathrm{~T}_{n}$, where $n-$ the number which is connecting these periods. For Earth $\mathrm{T}_{r o t}=24 \mathrm{~h}, \mathrm{~T}_{\pi}=160 \mathrm{~min} ., n=9$ (Table) [Andrade et al., 1972].

At the microlevel, confirmation of quantum-and-wave mechanics had became long-term research of N. Bohr, L. de Broil, E. Schrödinger since the beginning of the $20^{\text {th }}$ century. All other objects of microworld - elementary particles, cores, and molecules are also described by wave dynamic systems and wave equations. The indivisibility of particles and waves is described and mathematically with representation of a particle in the form of standing threedimensional waves. It is possible to describe such structure with rather high reliability as all natural phenomena have wave character with knowledge that all material environment is a congestion of three-dimensional spatial and temporary standing waves [Yavorskiy \& Detlaf, 1965]. The unity of particles and waves not only is applicable for physics, chemistry, but also takes place in biology and even sociology. Comparison of the main technical parameters with biological systems to some extent is not correct; however, the general principles of capsulation are identical. Including various biological objects sources of fluctuations of a zero order, Yakov Kumchenko has defined their periods of fluctuation of a surface for protein, $\gamma$-lipoproteid, mitochondrion, $\beta$-lipoproteid, cell of E.coli, bacteriophage $Z$, lipid, ribonukleoside, etc. It is established that all objects with taking into account attenuation of wave fluctuations have the period of $160.01 \mathrm{~min}$ that coincides with the period of fluctuation of cores of galaxies and planets (Table) [Kumchenko, 2005].

\section{Analysis of received results}

The analysis of conditions of open systems formation at various large-scale levels has allowed to reveal the similarity of appearance which is expressed in zonalities of energy distribution and matter and also the identical wave nature of their organization. This suggests about uniform energy source - the Universal wave field that operates by open energymaterial systems in which during stability losses, processes of convergence and divergence are actively developed with the purpose of equilibration of energy and matter structuring [Kirillov, 2005].

For confirmation of scientific novelty and practical value of the received results that are based on the data of modeling with the help of energy method of a research, comparison of the received results of research with the data established in the analysis of open systems on mega-, macro - and micro large-scale levels is executed. From the table it is visible that in large-scale level of system the core density is increasing, as both constant of gravitation and the period of fluctuation of systems surface. At the same time, a period of attenuation of wave fluctuations $\left(6.67 \cdot 10^{-11} \mathrm{cu} . \mathrm{m} / \mathrm{kg} \mathrm{s}^{2}\right)$ which has found the confirmation in results of modeling of factors of various intensity in the safety capsule of mine working in the course of extraction of minerals remains invariable. The law of formation of energy zones for all large-scale levels has been described by the sedate equations, $\mathrm{m}$

$$
\left.\begin{array}{l}
\text { - megalevel: } R_{n}-R=2\left(R_{n-1}-R\right) ; \\
\text { - macrolevel: } a=a_{n+1}-a_{n} ; \\
\text { - microlevel: } x_{n}=2 x_{n}-x_{n}
\end{array}\right\} \quad a_{i}=0.5 e^{0.7 n i}
$$

showing that each subsequent energy zone $n_{i}$ has the size twice exceeding previous one. Expression (1) completely coincides with the obtained verification dependences and data of modeling of parameters of mine workings capsulation. Comparison of modeling results of 
rocks condition around mine workings with the data received for systems on micro, macro and megalevels, shows identity of the revealed laws and almost 100 percent convergence of values for the received regularities. It says about the high level of convergence of the results of modeling that were received by means of energy method of the research which doesn't have the necessary comparative database nowadays [Khomenko et al., 2017].

\section{Conclusions}

1. The regularity of energy and matter distribution for various large-scale levels of open systems and the identical wave nature of their organization is determined. The uniform energy source - the Universal wave field is operated by open energy-material systems in which during stability losses, processes of convergence and divergence for the purpose of equilibration of energy and structuring matter actively developing. The analysis of origin of wave astrodynamics, a perspective of disclosure of physical essence of the phenomenon of zonal disintegration of rocks around mine workings and the analysis of results of the research that were received by means of the well-known and new methods have allowed opening phenomenon - zonal capsulation of mine workings in the massif of rocks. It is established that mine working is the epicenter of violation of energy balance in the massif of rocks. It leads to formation of the safety capsule that consisting of the system of ring energy zones where the sinusoidal fading autowave dependence on energy equilibration is happened: stress, density, temperature, magnetization, radioactivity, deformations. From mine working's contour to capsule border, amplitude of factors of intensity decreases, and the period of their action increases. It leads to destruction of rockss in near-the-contour zones (energy imbalance zones) and to increase in stresses in the zones (zones of energy balance) closing the capsule in comparison with the undisturbed massif of rocks.

2. The modeling of process of underground mine workings drivage in rocks with the durability of $40-200 \mathrm{MPa}$ and with mining depth of $0-3000 \mathrm{~m}$ has allowed to reveal verification sedate dependences which define a ratio of the sizes of energy zones. It is established that this ratio is a constant $\left(a_{n+1}-a_{n}=\mathbf{c o n s t}\right)$ on which shape and size of mine working, depth of its laying and properties of the containing massif don't influence. Increase in quantity of energy zones in the safety capsule of mine working happens during decreasing in rock strength and increase in mining depth that is described by multiple polynomial dependences of the fourth order. The universality of the offered energy method consists in determination of values of energy factors of intensity that increases the accuracy of modeling and forecasting rocks behavior.

3. Increase in large-scale level of system from micro (hydrogen atom, DNA molecule, mitochondrion cell) to mega- (Moon, Earth) and the macrolevel (Solar system, Galaxy, Metagalaxy) leads to equivalent increasing in density of core on polynomial dependence. Inasmuch as constant size of gravitation on logarithmic dependence and the period of fluctuation of a surface on polynomial dependence, and remain constants the period of attenuation of wave fluctuations $\left(6.67 \cdot 10^{-11} \mathrm{cu} . \mathrm{m} / \mathrm{kg} \cdot \mathrm{s}^{2}\right)$ and a ratio of the sizes of energy zones in all systems $\left(a_{i}=0.5 e^{0.7 \mathrm{ri}}\right)$. The received sedate dependence of a ratio of the sizes of energy zones for examined systems coincides with the established verification sedate dependences describing a ratio of the sizes of energy zones in mine working' capsule which convergence of values reaches up to $100 \%$. The received results are the incontestable evidence of the uniform nature of interaction of the open evolving systems at all large-scale levels and allows to draw analogies during development of methodological approaches to the solution of similar problems. 


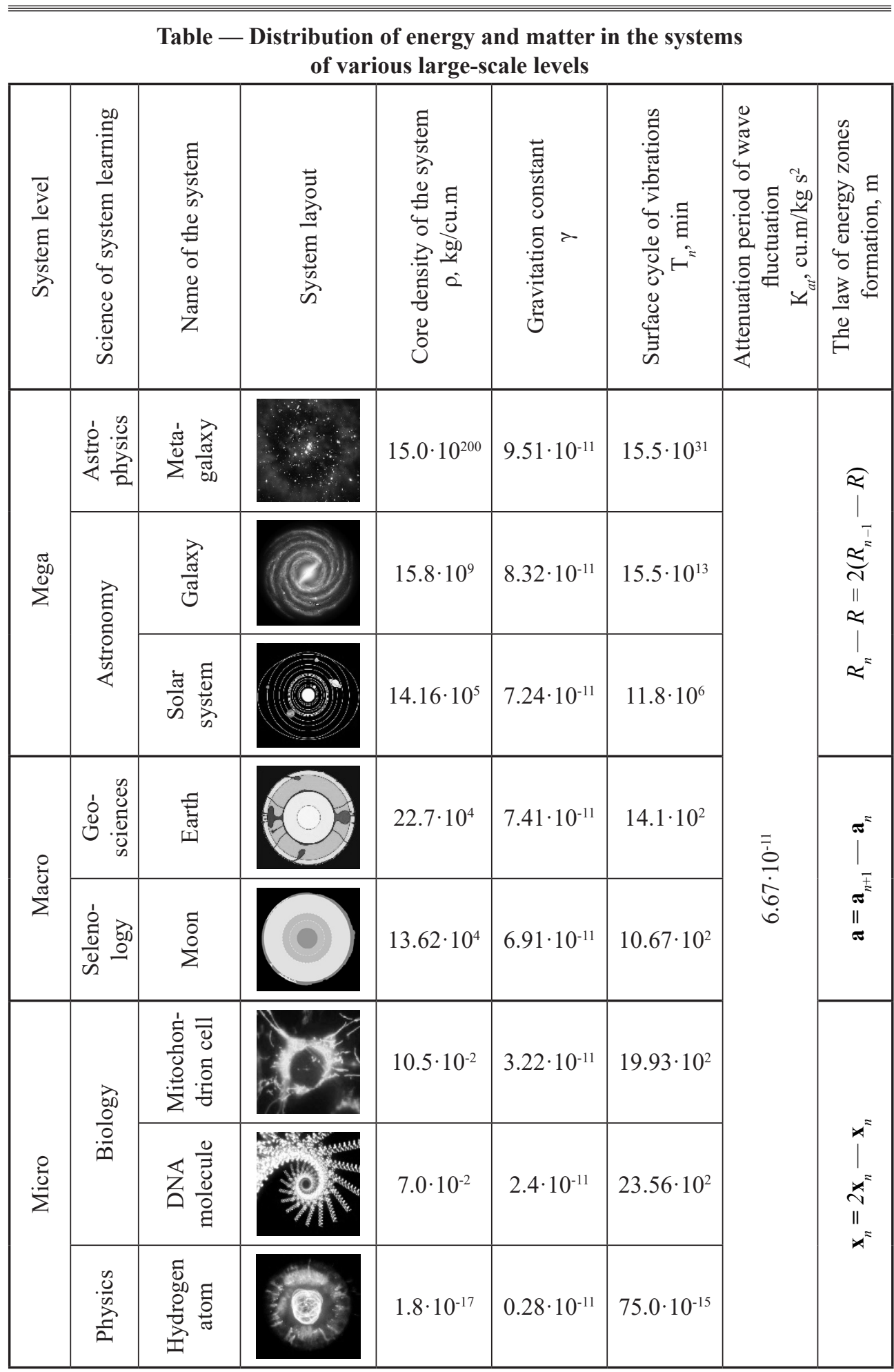




\section{References}

Andrade, Silva and Georges Lochak. Fields, particles, quanta. Translated from French. Moscow: Nauka, 1972.

Baisarov, Leonid, Mikhail Iliashov, Viktor Levitet. Discovery No. 318 Ukraine. Regularity of self-organization of soil and rock masses around elongated underground workings. (Otkrytie № 318 Ukraina. Zakonomernost samoorganizatsii gruntovykh i porodnykh massivov vokrug protyazhennykh podzemnykh vyrabotok). International Academy of Authors of Scientific Discoveries and Inventions, Application No. A-399 dated 20.04.2006. (in Russian).

Batiushkova, Irina. Internal structure of the Earth. (Vnutrenneye striyenie Zemli). Moscow: Nauka, 1966 (in Russian).

Bolotov, Boris. Human health in an unhealthy world. (Zdorovie cheloveka v nezdorovom mire). St. Petersburg: PITER, 2012 (in Russian).

Chechelnitsky, Albert. Extremum, stability, resonance in astrodynamics and cosmonautics. (Ekstremalnost, ustoichivost, rezonansnost $\mathrm{v}$ astrodinamike I kosmonavtike) Moscow: Mashinostroyenie, 1980 (in Russian).

Chechelnitsky, Albert. Uranium System, Solar System and wave astrodynamics. Forecast of the theory and "Voyager-2" observations. (Sistema Urana, Solnechnaya systema i volnovaya astrodinamika. Prognoz teorii i nabliudeniya "Voyager-2"). Reports of the AS of the USSR. Volume 303(5), 1988: 1082-1088 (in Russian).

Kaido, Ilmar. On the nature of phenomenon of zonal rock breaking around underground workings (hypothesis). (O prirode yavleniya zonalnoy dezintegratsii gornykh porod vokrug podzemnykh vyrabotok (gipoteza)). Mining Informational and Analytical Bulletin. Volume 1, 2009: 16-21 (in Russian).

Khomenko, Oleh, Maksym Kononenko, and Maksym Netecha. Industrial research into massif zonal fragmentation around mine workings. Mining of Mineral Deposits, Volume 10 (1), 2016: 50-56.

Khomenko, Oleh, Maksym Kononenko, and Aleksandr Dronov. Laboratory research on zonal structuring of a massif around mine workings. (Laboratornye issledovaniya zonalnogo strukturirovaniya massiva vokrug gornykh vyrabotok). Fiziko-tekhnicheskie problemy gornogo proizvodstva. Volume 18, 2016: 22-30 (in Russian).

Khomenko, Oleh. Sources of zoning the matter. (Istoki zonanlnogo raspredeleniya materii). Naukovyi Visnyk Natsionalnoho Hirnychoho Universytetu. Volume 3, 2007: 29-33 (in Russian).

Khomenko, Oleh. Implementation of energy method in study of zonal disintegration of rocks. Naukovyi Visnyk Natsionalnoho Hirnychoho Universytetu. Volume 4, 2012: 44-54.

Khomenko, Oleh. Geoenergetics of underground development of ore deposits: monograph. (Geoenergetika podzemnoy razrabotki rudnykh mestorozhdeniy: monografiya). Dnipro: DVNZ "NGU”, 2016 (in Russian).

Khomenko, Oleh, Andriy Sudakov, Zinjviy Malanchuk, and Yeygen Malanchuk. Principles of rock pressure energy usage during underground mining of deposits. Naukovyi Visnyk Natsionalnoho Hirnychoho Universytetu, Volume 2, 2017: 35-43.

Kirichenko, Vladimir, Yefim Zvyagilskiy, and Aleksandr Lishin. Discovery No. 188 Ukraine. Phenomenon of formation of traversing fractured zones in stressed rocks. (Otkrytie № 188 Ukraina. Yavlenie obrazovaniya peremeshchayushchikhsya zon v napryazhennykh gornykh porodakh). Collection of scientific discoveries, ideas, hypotheses. Moscow: RAEN, 2002: 62-63 (in Russian). 
Kirillov, Andrey. Outbursts of methane and coal concerning cosmophysical factors. Solar activity as the factor of space weather. Saint Petersburg, 2005: 75-80.

Kononenko, Maksym, Oleh Khomenko, Andrey Sudakov, Sergiy Drobot, and Tsendzgav Lkhagva. Numerical modelling of massif zonal structuring around underground working. Mining of Mineral Deposits. Volume 12 (3), 2016: 101-106.

Kumchenko, Yakov. Cosmic (Universal) sources of wave energy of the near space and far space by the example of rotation and circulation of the planets of the solar System and the Sun itself. Its wave invariant. (Vselenskiy (universalnyy) istochnik volnovoy energii blizhnego i dalnego kosmosa na primere vrashcheniya i obrashcheniya planet solnechnoy sistemy i samogo solntsa. Yego volnovoy invariant). Energy of the Earth, its geological-economic evidence, research and practice application. Kiev: IPC "KIEVSKIY UNIVERSITET", 2006 (in Russian).

Kumchenko, Yakov. Cosmic (Universal) sources of wave energy "KASHTUL" as a cause of creating the living matter. Its energetic leading the processes of origin, support and loss of life by the example of the terrestrial biosphere. (Vselenskiy (universalnyy) istochnik volnovoy energii "KASHTUL" kak prichina sotvoreniya zhivogo. Yego energeticheskoye soprovozhdeniye protsessov zarozhdeniya, podderzhaniya i gibeli zhizni na primere biosfery Zemli). Space and Biosphere, 2005: 55-57 (IN Russian).

Lavrinenko, Vladimir, and Valentina Lysak. Method for defining initial state of stress of hard rock masses. (Metod opredeleniya nachalnogo napryazhennogo sostoyaniya massivov gornykh porod). Razrabotka rudnykh mestorozhdeniy. Volume 24, 1977: 16-20 (in Russian).

Nieto, Michael Martin. The Titus-Bode Law of Planetary Distances: Its History and Theory. Translated by Yu.A. Riabov, 1976.

Shemiakin, Yevgeniy, Kurlenia, Mihkail. Oparin et al. Discovery No. 400 USSR. Phenomenon of zonal rock breaking around underground workings. (Otkrytie № 400 SSSR. Yavlenie zonalnoy dezintegratsii gornykh porod vokrug podzemnykh vyrabotok). BI SSSR. Volume 1, 1992. (in Russian).

Schmidt, Otto. A Theory of Earth's Origin: Four Lectures. (Chetyre lektsii o teorii proiskhozhdeniya Zemli). Moscow: AN SSSR, 1957 (in Russian).

Yavorskiy, Boris, and Andriy Detlaf. Reference book on Physics. (Spravochnik po fizike). Moscow: Nauka, 1965 (in Russian). 